RESEARCH NOTES

\title{
Soundscape of the Old Tatar Settlement: Historical and Cultural Meanings
}

\section{Paisaje sonoro del antiguo asentamiento tártaro: significados históricos y culturales}

\section{Rezeda Kamilevna Khurmatullina}

Candidate of pedagogical Sciences, associate Professor of the Department of world cultural heritage of the Institute of international relations of KFU, member of the international Council for Traditional Music (ICTM) at UNESCO, Kazan Federal University, Russia ORCID: 0000-0002-7975-2840

Zakia Abdullayevna Sapenova

Doctoral student of the Department of art history Kazakh national Academy of arts named after T. Zhurgenov, Almaty, Kazakh National Academy of Arts named after T. Zhurgenov, Kazakhstan

ORCID: 0000-0002-6729-5734

Received 09-08-20 Revised 10-10-20 Accepted 20-12-21 On line 03-01-21

* Correspondence

Email: rezeda-xurma@yandex.ru

\section{Citation:}

Khurmatullina Rezeda Kamilevna, Sapenova Zakia Abdullayevna. (2021). Soundscape of the Old Tatar Settlement: Historical and Cultura Meanings. Propósitos y Representaciones, 9(SPE2), e1050. http://dx.doi.org/10.20511/pyr2021.v9nSPE2.1050 


\begin{abstract}
The study of soundscape as a tool to study national culture, national identity formation has a huge potential in the historical, cultural, musicological, pedagogical, and other broad aspects. The Old Tatar settlement is one of the historic districts of Kazan; the architectural ensemble consisting of mosques which were the main location of social life of Tatars. However, the sound picture of the Old Tatar settlement's realities included acoustic images of various cultures and ethnicities, which contributed to the creation of a unique soundscape of the old Tatar settlement. We applied the methods of audio and video recordings, study of historical materials, descriptions, and recollections of old residents of this historical and cultural center of Kazan; the method of emotional immersion in the sound environment for recreation and linkages not only between objects of art and culture, but also between man and his object-cultural environment. The results showed that the history of the Tatar settlement is the history of the preservation of national identity. When Ivan the Terrible had conquered Kazan, all the Tatars were settled away from town. These people were given right to live only in the territory of the Old Tatar settlement. The logical consequence of that was the consolidation of religious forces of the Tatar people, which became the main spiritual factor of preserving the national identity. Muslim clergy had taken the function of cultural force. The formation of specific acoustic space of the Old Tatar settlement was closely connected with the construction of Muslim mosques with minarets. In addition to the ethno confessional factors in the properties of cultural landscapes, we have identified several private cultural spaces, including: historical, linguistic, professional and folk art, everyday culture. We have identified the main elements of the soundscape of the Old Tatar settlement and came to the conclusion that soundscapes play a huge role in the holistic perception of objects of cultural heritage.
\end{abstract}

Keywords: soundscape, Tatar culture, the Old Tatar Settlement.

\title{
Resumen
}

El estudio del paisaje sonoro como herramienta para estudiar la cultura nacional, la formación de la identidad nacional tiene un enorme potencial en los aspectos histórico, cultural, musicológico, pedagógico y otros amplios aspectos. El asentamiento Old Tatar es uno de los distritos históricos de Kazán; el conjunto arquitectónico formado por mezquitas que fueron el lugar principal de la vida social de los tártaros. Sin embargo, la imagen sonora de las realidades del antiguo asentamiento tártaro incluía imágenes acústicas de varias culturas y etnias, lo que contribuyó a la creación de un paisaje sonoro único del antiguo asentamiento tártaro. Aplicamos los métodos de grabaciones de audio y video, estudio de materiales históricos, descripciones y recuerdos de antiguos residentes de este centro histórico y cultural de Kazán; el método de inmersión emocional en el entorno sonoro para la recreación y los vínculos no solo entre objetos de arte y cultura, sino también entre el hombre y su entorno objeto-cultural. Los resultados mostraron que la historia del asentamiento tártaro es la historia de la preservación de la identidad nacional. Cuando Iván el Terrible conquistó Kazán, todos los tártaros se establecieron fuera de la ciudad. A estas personas se les dio derecho a vivir solo en el territorio del asentamiento tártaro antiguo. La consecuencia lógica de eso fue la consolidación de las fuerzas religiosas del pueblo tártaro, que se convirtió en el principal factor espiritual de preservación de la identidad nacional. El clero musulmán había asumido la función de fuerza cultural. La formación del espacio acústico específico del asentamiento tártaro antiguo estuvo estrechamente relacionada con la construcción de mezquitas musulmanas con minaretes. Además de los factores etnoconfesionales en las propiedades de los paisajes culturales, hemos identificado varios espacios culturales privados, que incluyen: arte histórico, lingüístico, profesional y popular, cultura cotidiana. Hemos identificado los elementos principales del paisaje sonoro del asentamiento tártaro antiguo y llegamos a la conclusión de que los paisajes sonoros juegan un papel muy importante en la percepción holística de los objetos del patrimonio cultural.

Palabras clave: paisaje sonoro, cultura tártara, el antiguo asentamiento tártaro. 


\section{Introduction}

Studying sound landscape as a part of national culture is a new and relevant task. Predominance of visual information in the society, low auditory culture, the problems of acoustic ecology sharpen the relevance of studying and preserving acoustic space as a part of culture. Thus, suggesting the concept of acoustic landscape, we imply that the notion of cultural landscape comprises natural and cultural components connected with each other and influencing each other, which are characteristic of a certain territory. By the term "acoustic landscape" we mean a set of traditional acoustic actions and certain acoustic reality which do take place in the daily life of a human being, defining the type of certain cultural territory. Acoustic landscape is one of the forms of expressing non-material cultural legacy connected with the cultural landscape: «oral traditions, including the language as the conductor of non-material cultural heritage; performing art: customs, rites and festivities: knowledge of nature and the Universe; knowledge's and skills connected with traditional arts» (The UNESCO Convention «On the protection of non-material cultural heritage», 2003).

It is possible to compare acoustic landscape with the sounds of an orchestra which comprises different groups of instruments with various tones depending on their function in the orchestra. Both in acoustic landscape and piece of music some instruments play simultaneously while in some moments only a part of the instruments produce sounds. Sounds intermingle with long or short pauses, which are also a means of musical expression; music is characterized by a variety of dynamical patterns, rhythms, tempo, etc.

The sounds of the surrounding world do indeed become the source of creative inspiration for many musicians, which is reflected in their autobiographical prose. K. Debussy once said: «Who can penetrate into the mystery of composing music? Sea murmur, curved line of the horizon, wind in the foliage, birds' squawking produce a variety of impressions on us. And then, without asking us, one of these impressions comes out to be expressed by the language of music. It carries its own harmony being so sincere and pure that it cannot be found elsewhere. It is only in this way that the heart prone to express itself via music makes the most wonderful discoveries» (Denisov, 1986). When asked what fuels her creative activity, Sofia Gubaidullina replied: «The most important is the sounds of the world, the sounds of everything surrounding me. Everything has its sound: the objects, the plants, the people, the ground, and the stars. If the person is enough concentrated, he will hear it ...» (http://place-fact.com).

The Canadian composer, educator and prose writer R.M. Shaffer was one of the first who pointed out the problem of preserving the acoustic picture of the world in the era of industrial civilization. He wrote: «one of the possible definitions of noise is that it is defined as the sounds which we are taught to ignore. We have been ignoring them for so long that they have completely run out of control. In my approach, which tackles this problem, I consider the world acoustic landscape to be a gigantic macrocosmic composition which is constantly created around us. The human being is the main creator of this composition; it is in his power to make it more (or less) beautiful» (Shaffer, 1990).

Supporting this idea, Russian cultural studies expert E.D. Andreeva writes in her article called «Acoustic landscape as a real object and research task»: «each epoch and culture has its own voice - its acoustic contents, form and performance» (Andreeva, 2000). The acoustic form is made up of systemic sounds which appear as a result of regularly repeated phenomena connected with nature or the human activity in a certain territory. E.D. Andreeva emphasizes the fact that acoustic landscapes play a significant role in the perceptual unity of the objects of cultural heritage. She develops this idea basing on the example of the organization of acoustic space in the historical cultural landscapes of conservation areas. She gives convincing argumentation saying that the harmonization of the conservation areas territory by means of the restoration of traditional acoustic patterns will make for better historical cultural authenticity, point out ethnical identity, create esthetic integrity, intensify associated perception, and will produce the effect of deeper immersion into a certain historical cultural atmosphere. 


\section{Materials and Methods}

We applied the methods of audio and video recordings, study of historical materials, descriptions, and recollections of old residents of this historical and cultural center of Kazan; the method of emotional immersion in the sound environment for recreation and linkages not only between objects of art and culture, but also between man and his object-cultural environment.

The Old Tatar settlement is one of the historic districts of Kazan; the architectural ensemble consisting of mosques which were the main location of social life. When Ivan the Terrible had conquered Kazan, all the Tatars were settled away from town. There were only few falling into the tsar's favour who was allowed to stay; they were mainly merchants. These people were given right to live only in the territory of the Old Tatar settlement and were threatened to be killed if they had dared to appear in the Kremlin area. «After the fall of the Kazan khanate in 1552, on the territory of the Middle Volga region, the Urals and Siberia, the Russian State launched an active large-scale missionary policy towards the Turkic, Finno-Ugric and Mongolian ethnic groups. Its main purpose was to destruct the foundations of Islam, forced Christianisation, Russification...» (Vyazov et al., 2019).

In actual fact, the Old Tatar settlement was the only monument of the urban culture of the Kazan Tatars. After the loss of the Tatar state the Tatars found themselves in new historical reality. Expulsion of the Tatars from towns had led to the situation that they were deprived of their national urban layer. The Christianization policy was as well contributing to this state of affairs. So, the Tatar culture was suffering extremely difficult life conditions. The logical consequence of that was the consolidation of religious forces of the Tatar people, which became the main spiritual factor of preserving the national identity. Muslim clergy had taken the function of cultural force. Islam was suffering persecution, however, this fact only promoted its popularity among the people. «All those who visit these places will undoubtedly find it strange to discover that in general the Tatars are more literate than even some European peoples. A Tatar who cannot read and write is detested by his own fellows and is not usually respected as a citizen. That is why each father tries to sign up his children for school, where they could be taught at least to write, read and could be acquainted with the foundations of religion. To support this initiative, each mosque was supposed to contain a school which was specifically controlled by the bishop (akhoun) », - this was what Karl Fuchs wrote in 1844 (Fuchs, 1844).

The formation of specific acoustic space of the Old Tatar settlement was closely connected with the construction of Muslim mosques with minarets. Minarets served as sound amplifiers for the muezzins, who needed to provide loud distribution of religious information, calling the Muslims to pray. Minarets were unique material and at the same time spiritual vehicles of the specific acoustic landscape. For instance, the Nuroullah mosque was the main Kazan mosque before the Revolution (the picture Nurullah mosque). 


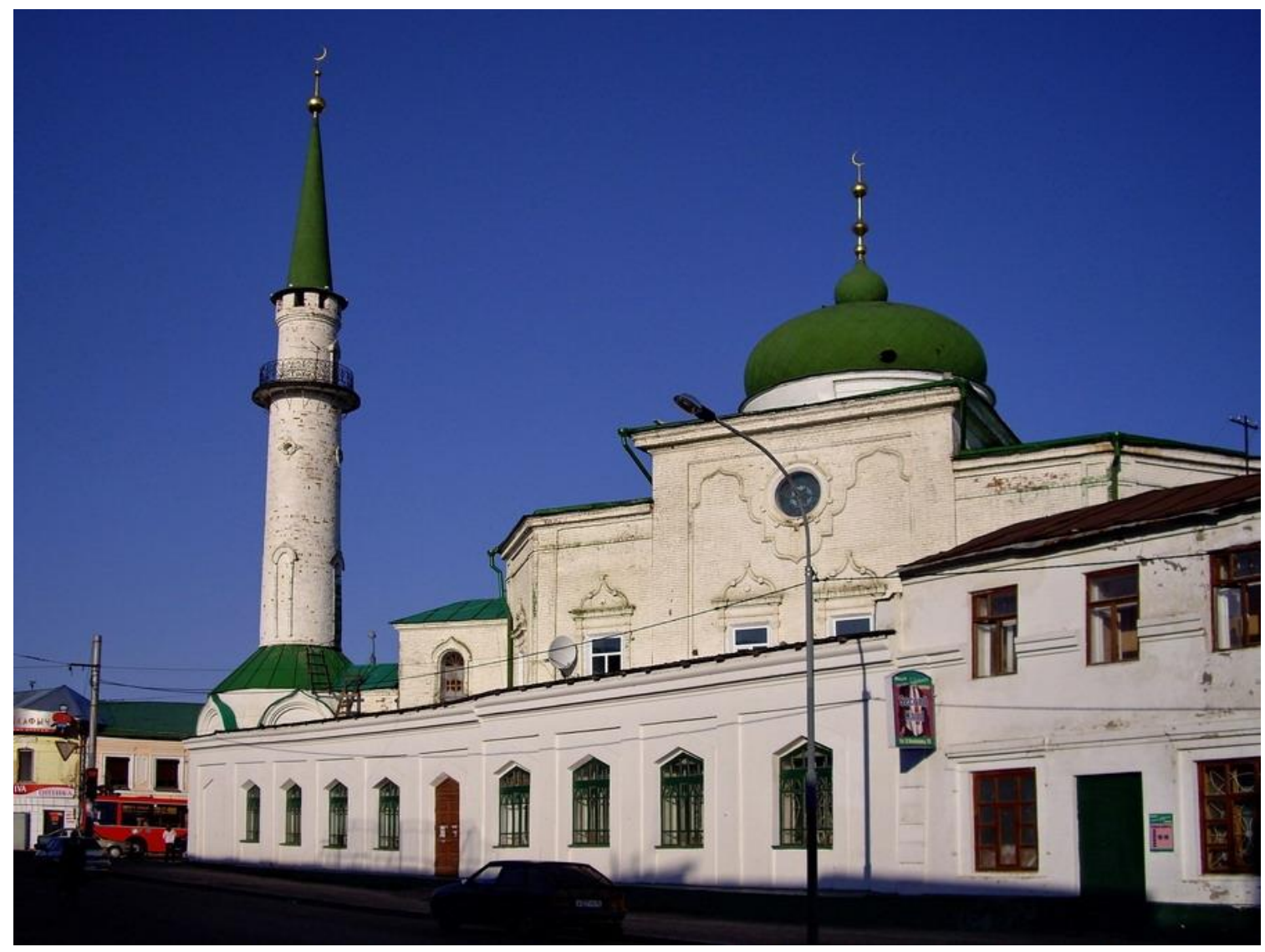

Pic.1. Nurullah mosque

The romantic image of the mosque appeared because of its minaret's form which reminded of the Bolgar minarets. The cylindrical shank of the minaret, which gets thin at its top, rests upon the hexagonal tambour with cone-shaped cover. It is completed by a low tier with small rectangular apertures, which are associated with the castellation of medieval towers. Using spiral stairs of the almost blind shank a person can ascend to the circular azanchi balcony.

Religious ministers were supposed to meet certain demands: a beautiful, loud voice, clear pronunciation, the knowledge of the main melodical formulas - maqams, the ability to embroider the melody in a beautiful way. Thus, the main sources of the acoustic landscape of the Old Tatar settlement were the mosques, being ethnic confessional facilities with peculiar inner and outer architectural acoustics.

Apart from ethnic confessional factors, cultural landscapes are characterized by several "particular cultural spaces" including historical, linguistic, the space of professional and folk art, the space of popular culture. It is easy to notice that all these "spaces" have their own sounds, which may be the property of inner differentiation. Thus, linguistic space is connected with natural languages which are the means of oral, i.e. sound communication. The space of professional and folk art does not only comprise multitudes of sound components but also the huge sphere of music, which deals only with sounds. The space of popular culture can also be characterized by rich acoustic palette. Since acoustic landscape as a part of cultural landscape is liable to change throughout time, it is possible to distinguish its acoustic constituent.

One of the methods of acoustic sphere investigation is the analysis of people's sensations which describe typical sounds of the given location or period of time. It helps to identify certain changes in the perception of sounds throughout time. Another method is reconstruction of the acoustic atmosphere of the past and acoustic reproduction of settled traditional cultural traits.

The reminiscences of an old-time resident of the Old Tatar settlement Nuraniya Biktimirova at the beginning of the XX-th century tell us the following «...the settlement had 
straight accurate parallel streets adjoined by cozy alleyways. Each house had a yard and garden. In May the settlement smothered in flowers. The yards were blocked out by thickets with apple, cherry, pear trees, lilac growing inside - the whole settlement was blossoming. ... The people lived like a family surrounded by all those mosques; it was called makhalla. All religious and secular occasions were celebrated together with the people paying visits to one another. There existed a nice tradition to invite each other for a cup of tea in the evening. ... songs were popular. The people listened to songs using gramophones, radio. Everyone played musical instruments. My brother played accordion, which was considered prestigious. Musicians were always invited for weddings and special events; those who played well were paid money. Renowned musicians Irkiya Ibraghimova and Roustam Akhmadiev lived in the Old Tatar settlement, Tukai Street, 102. I remember there was an elderly man who played violin. He would go door to door and played; the people would give him money or just treated him to different things. Everyone would come out of the house to listen to him, my grandma was always crying...» (http://www.sobaka.ru).

What about the sound of the old Tatar settlement today? According to audio and video recordings, you can hear the gulls honking somewhere over the Volga, farewell hoots of the departing cruise liners, the echoes of azans from the nearest mosques «Nuroullah», «Iske-tash», «Soultanovskaya», the noise of the passing trains and the talks of the railroad station controllers, the Babel dissonance coming from the Kolkhozniy and Clothes Markets. In fair weather during Christian holidays you can hear the ringing bells of the nearest churches. The Old Tatar settlement is the most dynamic part of the city today. It is right here that the very boiling pot or kazan (Tat.) (hence the city's name) is situated.

«...each of us in his turn is destined to hear the call of blood and to feel the blood connection with his native land» (Safin et al., 2018).

\section{Results}

The formation of specific acoustic space of the Old Tatar settlement was closely connected with the construction of Muslim mosques with minarets. Muslim clergy had taken the function of cultural force, which became the main spiritual factor of preserving the national identity. Along with that, the acoustic scores of the Old Tatar settlement have absorbed the acoustic images of different cultures and ethnos, mainly Turk, Islam, and Russian (Khurmatullina \& Salpykova, 2014). The process of interaction of "acoustic masses" of different cultures involved ethnic confessional institutions with the regulations requiring very accurate acoustic composition of the religious actions which occur in them. They created a specific and unique acoustic image of the Old Tatar settlement. In addition to the ethno - confessional factors in the properties of cultural landscapes, we have identified several private cultural spaces, including: historical, linguistic, professional and folk art, everyday culture, intercultural communication in the ever-expanding multicultural space (Karkina, 2015).

\section{Discussion}

The study of soundscape as part of the national culture is the new challenge. Special contribution to the study of the problem of sonic landscapes was introduced by the Russian musicologist, sociologist and scholar E. D. Andreeva (2000). Among cultural studies on this topic include the works of D. Zakharyin (2009), Y. Druskin (2010) and V. Matasov (2008). The works of the Canadian scientist R. M. Schaeffer (Shaffer, 1990) are fundamental in this area.

But questions about the effect of sound environment on the national culture remain open. The lack of reliable methods for the study of the sound space is obvious. The method of analysis of soundscapes requires further development, development, and classification of the audio timbraltextural structures, the criteria for the allocation of various types of relief and background sounds. All of this is a huge field further research in this area. The study of acoustic landscape as a tool to study national culture, national identity formation has a huge potential in the historical, cultural, musicological, pedagogical, and other broad aspects. 


\section{Conclusion}

The history of the Tatar settlement is the history of the preservation of national identity. The formation of specific acoustic space of the Old Tatar settlement was closely connected with the construction of Muslim mosques with minarets. In addition to the ethno - confessional factors in the properties of cultural landscapes, we have identified several private cultural spaces, including: historical, linguistic, professional and folk art, everyday culture. Along with that, the acoustic scores of the Old Tatar settlement have absorbed the acoustic images of different cultures and ethnos. We have identified the main elements of the acoustic landscape of the Old Tatar settlement and came to the conclusion that soundscapes play a huge role in the holistic perception of objects of cultural heritage.

\section{Acknowledgements}

The work is performed according to the Russian Government Program of Competitive Growth of Kazan Federal University.

\section{References}

Andreeva, E. D. (2000). Acoustic landscape as a real object and research problem // Ecology of culture. - M.

Denisov, E. (1986). Modern music and the problems of evolution of composition techniques. - M.: The Soviet composer.

Druzhkin, Y. (2010). Soundscapes of cultural spaces. Sound and resound. - M., The Heritage Institute, 252-264.

Electronic source: http://place-fact.com/place/17628/fact/15 (Date of reference - 22.05.2019).

Electronic source: http://www.sobaka.ru/kzn/lifestyle/realty/37664 (Date of reference 18.05.2019).

Fuchs, K. (1844). The Kazan Tatars with regard to statistics and ethnography - Kazan.

Karkina, S.V. (2015). The works of N.Harnoncourt: The dynamics of style on the example of performances of Mozart's opera "La Clemenza di Tito" period of the late XX c. and early XXI c. 2nd International Multidisciplinary Scientific Conference on Social Sciences and Arts SGEM, 26.08 - 01.09.2015, Albena, Bulgaria, Book 4 Arts, Performing Arts, Architecture and Design, 139-146.

Khurmatullina, R.C., \& Salpykova, I.M. (2014). Tatar folklore in the creative work of composer Rafael Belyalov// Middle-East Journal of Scientific Research, 19(1), 29-41. http://www.idosi.org/mejsr/mejsr19(1)14/6.pdf

Matasow, V. (2008). Problems of the study of soundscapes. Modern problems of landscape science and Geoecology: materials of IV International scientific conference devoted to 100-anniversary of birthday of Professor V. A. Dementyev (1908-1974), 14-17 Oct. Minsk, 73-75.

Safin, M.F., Khabutdinova, M.M., \& Khabutdinov, A.J. (2018). The theme of muhajirlik in tatar prose [El tema del muhajirlik en la prosa tártara]. Opcion, 34(86), 119-126.

Shaffer, M. (1990). Thoughts on musical education // From the history of musical education: Anthology / Compiler O. A. Apraksina. - M.: Prosveshchenie.

The UNESCO Convention «On the protection of non-material cultural heritage», 2003.

Vyazov, L.A., Ershova, E.G., Ponomarenko, E.V., Gajewski, K., Blinnikov, M.S., \& Sitdikov, A.G. (2019). Demographic changes, trade routes, and the formation of anthropogenic landscapes in the middle Volga region in the past 2500 years. Socio-Environmental Dynamics Along the Historical Silk Road, 411-452.

Zakhar'in, D. (2009). From soundscape to sound design. Anthropological forum: No. 11. Dmitry Zakhar'in 'in. - SPb, 135-183. 